\title{
Micropropgation of caper (Capparis spinosa L.) from wild plants growing in North Sinai
}

\author{
El-Mekawy, M. A., M. A. M. Ali, A. H. Belal and S. A. S. Abdallah \\ Plant Production and Protection Department, Faculty of Environmental Agricultural Sciences El-Arish, Suez Canal \\ University, Egypt
}

Received: $9 / 5 / 2012$

\begin{abstract}
The effect of various treatments on the behavior of in vitro consecutive micropropagation stages of Capparis spinosa L. was studied and a micropropagation protocol was developed. Three media were tested Murashige and Skoog (MS), Linsmaier and Skoog (LS) and Nitsch and Nitsch (NN) with shoot-tip and one node cutting for the establishment stage. Murashige and Skoog (MS) was found to be the best medium and one node cutting as starting materials for establishment from mother plants. Multiple shoots were obtained on MS medium supplemented with $0.50 \mathrm{mgl}^{-1} 6$ benzyladenine (BA) in the combination with $0.05 \mathrm{mgl}^{-1} \alpha$-naphthaleneacetic acid (NAA). High frequency (85\%) of rooting was obtained on 1/2MS semi solid medium supplemented with $1.5 \mathrm{mgl}^{-1}$ Indole-3-butyric acid (IBA) alone or with $2 \mathrm{gl}^{-1}$ activated charcoal (AC). Regenerated plantlets were successfully transferred to pots containing mixture of peat-moss and vermiculite at equal volume with $90 \%$ survival.
\end{abstract}

Keywords: Capparis spinosa L., Micropropgation, nodal culture, survival rate, Activated charcoal.

\section{INTRODUCTION}

Capparis spinosa L. (caper) belonging to Family Cappariaceae and an indigenous perennial of most Mediterranean countries (Chalak and Elbiter 2006) and (Musallam et al., 2011). In Egypt, C. spinosa is very rare plant which distributed wild in North Sinai (Raafaat et al., 2008) this shrub has become an interesting and specialized crop of great economic importance in the Mediterranean area over the last 10 years (Rodriguez et $a l .$, 1990) this perennial shrub plant has thick and deep roots, and is about $30-100 \mathrm{~cm}$ (high), and it can be thorny or inerm. C. spinosa is one of the most commonly found aromatics in the Mediterranean kitchen, it employed as a flavoring in cooking and as a diuretic, hypertensive and tonic since ancient time. $C$. spinosa plant contains several chemically active constituents but one of the most important classes of compounds present is the flavonoids (Rodriguez et al., 1990).

Capparis spinosa usually propagated by seed and cutting where both methods of propagation present serious problems, being one of the greatest restrictions to the commercial expansion of this crop. The poor germination capacity of caper seeds due to seed dormancy and the serious rooting problem associated with its lignified and herbaceous cutting have been cited Tansi (1999) Solyer and Khawar (2007) and Germana and Chiancone (2009). All these reasons increase the risk of losing genetic resources of the plans so large scale multiplication, tissue culture techniques could overcome these problems. Either for increasing genetic variability or for clonal multiplication of selected genotype.

In vitro culture of caper was first reported in 1984 (Ancora and Cuozzo 1985) using vegetative material. Subsequently, propagation was reported by several authors starting mainly from nodal segments (Rodriguez et al., 1990; Salem et al., 2001; Chalak et al.. 2006; Caglar et al., 2005; Musallam et al., 2011; Al-Safadi and Elias 2011 and Carra et al., 2012) even if also seedlings were used (Horshati and Jambor-Benczur 2006 and Movafeghi et al., 2008) In vitro caper cultivation from nodal explants presents some problems focused mainly during establishment of axenic culture (Chalak and Elbitar, 2006 and Carra et al., 2011). In vitro rooting is another crucial step and even if several authors reported high successful percentages (80$100 \%$ ), rooting induction requires high levels of auxins that stimulates callus formation (Chalak and Elbitar 2006 and Musallam et al., 2011).

In this study, we aim to establish an applicable protocol to in vitro propagation of Capparis spinosa.

\section{MATERIALS AND METHODS}

\section{Plant Material}

Plant material was collected from mature plants Capparis spinosa grown naturally in North Sinai (El Hasana), Egypt. Plant material was wrapped with wet paper and transferred in ice box to the lab of the Tissue Culture Unit at the Faculty of Environmental Agricultural Sciences, El-Arish, Suez Canal University.

\section{Explant sterilization}

Shoot tip and one node cutting explants $(2-3 \mathrm{~cm})$ in length were excised and washed under running tap water for $1 \mathrm{hr}$ agitated in tap water with a few drops of liquid soap for 5 minutes. The explants were soaked for 5 minutes in $30 \%$ Clorox (containing 5.25\% sodium hypochlorite) then washed again with sterilized distilled water for 3-5 times to remove all traces of the disinfection. All traces of the used disinfectants were removed by soaking and rinsing the explants for 3-5 times with sterile distilled water.

\section{Culture Medium}

The MS, LS and NN media containing macro and micro elements as well as vitamins, according to Murashige and Skoog (MS,1962), Linsmaier and Skoog (LS, 1965) and Nitsch and Nitsch (NN , 1969 ) were used through this study as shown in (Table 1 and 2) .The media were supplemented with $100 \mathrm{mgl}^{-1}$ myo- 
inositol and $3 \%$ sucrose. All media were adjusted to pH $5.7-5.8$ using either $0.10 \mathrm{~N} \mathrm{NaOH}$ or $0.10 \mathrm{~N} \mathrm{HCL}$ depending upon high or low before gelling with $7.00 \mathrm{gl}^{-}$ ${ }^{1}$ agar in all stages and the medium was cooked in the hot plate.

The media were dispensed into tissue culture jars, each jar contained $15 \mathrm{ml}$ of culture medium. Sterilization of the medium was achieved by autoclaving the jars containing media under pressure of $1.1 \mathrm{~kg} / \mathrm{cm} 2$ and at $120^{\circ} \mathrm{C}$ for 20 minutes. The jars were transferred to the culture cabinet and left to cool in a slanted position till they were used. Cultured jars were transferred to growth room and maintained at $\left(26^{\circ} \pm 2 \mathrm{C}\right.$, $16 \mathrm{hrs}$ light and $8 \mathrm{hrs}$ darkness)

\section{Establishment stage:}

To examine the best medium and explant for establishment of Caper, shoot tip and one node cutting were cultured on three different media MS, LS and NN.

Scores were given for necrosis estimated as the degree of dead tissues or parts and browning termed as all medium darkened $=5$, the most of explants dead and the most medium darkened $=4$, medium $=3$, less than medium $=2$, while the healthy and no browning $=1$. Also explant development (measured as any changed occurred in the explant). Greening (defined as the degree of keeping the original color of the explant and the green color of the leaves. All these data calculated visually accordind to Pottino (1981).

\section{Shoot Multiplication}

Nodal segments (2-3 cm long) which obtained from establishment stage containing two axillary buds were cut and cultured on MS medium containing BA (0.00, $0.50,1.00,2.00,3.00$ and $4.00 \mathrm{mgl}^{-1}$ ) in combination with $\alpha$-naphthaleneacetic acid NAA at $0.05 \mathrm{mgl}^{-1}$ ). Explants were subcultured every four weeks. After four weeks of subculture, data were recorded on number of shoots, shoot length and number of leaves.

\section{Rooting stage}

For rooting, individual shoots of 3-4 cm long which obtained from multiplication stage were excised from the proliferated shoots and cultured on full, 50 and $25 \%$ strengths MS of basal medium supplemented either with $1.00 \mathrm{mgl}^{-1}$ indole-3- butyric acid (IBA) or $1.00 \mathrm{mgl}^{-1}$
NAA to determined which the best media strength and type of auxin maximized the high percentage of root Also, Isolated shoot were inoculated aseptically on $1 / 2 \mathrm{MS}$ medium with $1.00 \mathrm{mgl}^{-1}$ IBA in solid, semi-solid and liquid. Shoots were cultured on $1 / 2$ MS semi solid media with different concentrations of IBA $(0.00,0.50$, $1.00,1.50$ and $2.00 \mathrm{mgl}^{-1}$ ) alone or with $2.00 \mathrm{gl}^{-1} \mathrm{AC}$. Shoots were cultured on these media for six weeks, and the data was recorded as number of main roots, number of lateral roots, root length and plant length

\section{Acclimatization of plantlets}

Plantlets were transplanted into plastic pots containing autoclaved mixture of peat-moss and vermiculite $(1: 1 \mathrm{v} / \mathrm{v})$ and covered with polyethylene bags, which were tightly closed to maintain high humidity. The plantlets were watered with 0.25 strength Hoagland's solution once a week for a period of 3 weeks. Thereafter, the polyethylene bags were removed and plantlets were maintained under nursery conditions.

\section{Statistical analysis}

There were four replicates containing four explants for each jar for each treatment and data were tested using the analysis of variance (ANOV) by the General Linear Models (GLMs) procedures using SAS (SAS, 2004). Where a significant difference was observed for a measured value, means were separated using Duncan's multiple range test (DMRT) (Duncan, 1995) at the $5 \%$ level.

\section{RESULTS AND DISCUSSION}

\section{Establishment stage \\ Effect of medium and explant type}

Regarding the effect of interaction between medium type and explant type it is noticed from (Table 1) that culturing of one node cutting on MS medium induced significant reduction in necrosis and browning while increased both explant development and greening parameters. The superiority of one node cutting with MS media obtained by (Caglar et al., 2005; Chalak, and Elbitar 2006; Khattab and Ibenthal 2010 and Carra et al., 2012) for C. spinosa and Chahar et al., (2010) for $C$. deciduas.

Table (1): Effect of interaction between medium and explant types on explant development accordind to Pottino (1981).

\begin{tabular}{|c|c|c|c|c|c|}
\hline Medium type & $\begin{array}{l}\text { Explant } \\
\text { Types }\end{array}$ & Necrosis & Browning & $\begin{array}{c}\text { Explant } \\
\text { development }\end{array}$ & Greening \\
\hline Murashige \& Skoog & $\begin{array}{c}\text { Shoot tip } \\
\text { One-node cutting }\end{array}$ & $\begin{array}{l}2.92^{\mathrm{ab}} \\
1.11^{\mathrm{d}}\end{array}$ & $\begin{array}{l}1.89^{\mathrm{c}} \\
1.56^{\mathrm{d}}\end{array}$ & $\begin{array}{l}3.14^{\mathrm{b}} \\
4.10^{\mathrm{a}}\end{array}$ & $\begin{array}{l}2.83^{\mathrm{b}} \\
4.78^{\mathrm{a}}\end{array}$ \\
\hline Linsmaier \& Skoog & $\begin{array}{c}\text { Shoot tip } \\
\text { One-node cutting }\end{array}$ & $\begin{array}{l}2.44^{\mathrm{b}} \\
1.78^{\mathrm{ab}}\end{array}$ & $\begin{array}{l}3.10^{\mathrm{a}} \\
2.33^{\mathrm{b}}\end{array}$ & $\begin{array}{l}1.94^{\mathrm{d}} \\
2.53^{\mathrm{c}}\end{array}$ & $\begin{array}{l}1.36^{\mathrm{d}} \\
1.73^{\mathrm{d}}\end{array}$ \\
\hline Nitsch \& Nitsch & $\begin{array}{c}\text { Shoot tip } \\
\text { One-node cutting }\end{array}$ & $\begin{array}{l}3.67^{\mathrm{a}} \\
3.00^{\mathrm{b}}\end{array}$ & $\begin{array}{l}2.97^{\mathrm{a}} \\
2.59^{\mathrm{b}}\end{array}$ & $\begin{array}{l}2.36^{\mathrm{c}} \\
3.11^{\mathrm{b}}\end{array}$ & $\begin{array}{l}2.23^{c} \\
2.16^{c}\end{array}$ \\
\hline
\end{tabular}

Means followed by the same letter within each column are not significantly different at 0.05 level of probability according to Duncan's multiple range test 
Table (2): Effect of BA concentrations on number of shoots, shoot length and number of leaves during multiplication stage.

\begin{tabular}{cccc}
\hline $\begin{array}{c}\text { Concentration } \\
\text { mgl }^{-1}\end{array}$ & $\begin{array}{c}\text { No. of } \\
\text { shoots }\end{array}$ & $\begin{array}{c}\text { Shoot } \\
\text { Length (cm) }\end{array}$ & $\begin{array}{c}\text { No. of } \\
\text { Leaves }\end{array}$ \\
\hline 0.00 & $2.78^{\mathrm{b}}$ & $2.29^{\mathrm{c}}$ & $17.56^{\mathrm{c}}$ \\
0.50 & $3.89^{\mathrm{a}}$ & $3.24^{\mathrm{a}}$ & $24.22^{\mathrm{a}}$ \\
1.00 & $3.11^{\mathrm{b}}$ & $2.29^{\mathrm{c}}$ & $20.67^{\mathrm{c}}$ \\
2.00 & $3.22^{\mathrm{b}}$ & $2.14^{\mathrm{c}}$ & $20.22^{\mathrm{bc}}$ \\
3.00 & $2.89^{\mathrm{b}}$ & $2.43^{\mathrm{bc}}$ & $20.44^{\mathrm{bc}}$ \\
4.00 & $3.00^{\mathrm{b}}$ & $2.67^{\mathrm{b}}$ & $21.33^{\mathrm{b}}$ \\
\hline
\end{tabular}

Means followed by the same letter within each column are not significantly different at 0.05 level of probability according to Duncan's multiple range test.

Table (3): Interaction effect of MS medium strength and type of Auxin on number of main roosts, number of lateral roots, root length and plant length.

\begin{tabular}{cccccc}
\hline $\begin{array}{c}\text { MS medium } \\
\text { strength }\end{array}$ & $\begin{array}{c}\text { Type of Auxin } \\
\text { (1 mg/l) }\end{array}$ & $\begin{array}{c}\text { No. of } \\
\text { main roots }\end{array}$ & $\begin{array}{c}\text { No. of } \\
\text { lateral roots }\end{array}$ & $\begin{array}{c}\text { Root } \\
\text { length } \\
\text { (cm) }\end{array}$ & $\begin{array}{c}\text { plant } \\
\text { length } \\
\text { (cm) }\end{array}$ \\
\hline \multirow{2}{*}{ Full } & IBA & $1.87^{\mathrm{b}}$ & $17.11^{\mathrm{b}}$ & $5.51^{\mathrm{bc}}$ & $3.22^{\mathrm{a}}$ \\
& NAA & $2.33^{\mathrm{b}}$ & $14.67^{\mathrm{bc}}$ & $5.16^{\mathrm{c}}$ & $2.63^{\mathrm{bc}}$ \\
Half & & & & $7.30^{\mathrm{a}}$ & $3.36^{\mathrm{a}}$ \\
& IBA & $3.44^{\mathrm{a}}$ & $20.78^{\mathrm{a}}$ & $6.00^{\mathrm{b}}$ & $2.89^{\mathrm{ab}}$ \\
\multirow{2}{*}{ Quarter } & NAA & $2.23^{\mathrm{b}}$ & $13.11^{\mathrm{cd}}$ & & \\
& & & $3.54^{\mathrm{d}}$ & $2.30^{\mathrm{cd}}$ \\
\hline
\end{tabular}

Means followed by the same letter within each column are not significantly different at 0.05 level of probability according to Duncan's multiple range test

Table (4): Effect of different medium state with half medium strength with $1 \mathrm{mgl}^{-1}$ IBA on number of main roosts, No. of lateral roots, root length and plant length.

\begin{tabular}{llllll}
\hline Medium & $\begin{array}{l}\text { medium } \\
\text { state }\end{array}$ & $\begin{array}{l}\text { No. of } \\
\text { main roots }\end{array}$ & $\begin{array}{l}\text { No. of } \\
\text { lateral roots }\end{array}$ & $\begin{array}{l}\text { Root } \\
\text { Length (cm) }\end{array}$ & $\begin{array}{l}\text { plant } \\
\text { length (cm) }\end{array}$ \\
\hline \multirow{2}{*}{ Half MS } & Solid & $2.00^{\mathrm{b}}$ & $23.22^{\mathrm{b}}$ & $4.20^{\mathrm{b}}$ & $2.02^{\mathrm{ab}}$ \\
& Semi Solid & $2.44^{\mathrm{a}}$ & $32.00^{\mathrm{a}}$ & $5.33^{\mathrm{a}}$ & $2.31^{\mathrm{a}}$ \\
& Liquid & $1.33^{\mathrm{c}}$ & $14.00^{\mathrm{c}}$ & $3.31^{\mathrm{c}}$ & $1.75^{\mathrm{b}}$ \\
\hline
\end{tabular}

Means followed by the same letter within each column are not significantly different at 0.05 level of probability according to Duncan's multiple range test

Table (5): Effect of different concentrations of IBA on number of main roosts, number of lateral roots, root Length and plant length.

\begin{tabular}{ccccc}
\hline $\begin{array}{c}\text { Concentration } \\
\text { mgl }^{-1}\end{array}$ & $\begin{array}{c}\text { No. of } \\
\text { main roots }\end{array}$ & $\begin{array}{c}\text { No. of } \\
\text { lateral roots }\end{array}$ & $\begin{array}{c}\text { Root } \\
\text { Length (cm) }\end{array}$ & $\begin{array}{c}\text { plant } \\
\text { length (cm) }\end{array}$ \\
\hline 0.00 & $2.44^{\mathrm{b}}$ & $21.00^{\mathrm{b}}$ & $4.32^{\mathrm{b}}$ & $2.19^{\mathrm{c}}$ \\
0.50 & $2.11^{\mathrm{b}}$ & $18.56^{\mathrm{b}}$ & $4.03^{\mathrm{b}}$ & $2.52^{\mathrm{bc}}$ \\
1.00 & $2.58^{\mathrm{b}}$ & $20.11^{\mathrm{b}}$ & $4.42^{\mathrm{b}}$ & $2.81^{\mathrm{ab}}$ \\
1.50 & $3.67^{\mathrm{a}}$ & $27.22^{\mathrm{a}}$ & $5.39^{\mathrm{a}}$ & $3.03^{\mathrm{a}}$ \\
2.00 & $2.78^{\mathrm{b}}$ & $20.44^{\mathrm{b}}$ & $4.01^{\mathrm{b}}$ & $2.69^{\mathrm{ab}}$ \\
\hline
\end{tabular}

Means followed by the same letter within each column are not significantly different at 0.05 level of probability according to Duncan's multiple range test 
However, Musallam (2011) found the woody plant medium (WPM) was the best medium with one-node cuttings from mother plants for $C$. spinosa comparing with MS. On the other hand, Hassanein et al., (2008) found the shoot tip on MS medium was the best combination for $C$. cartilaginea compared with one node cutting on MS meduim.

\section{Shoot Multiplication:}

Effects of various concentrations from BA $(0.00$, $0.50,1.00,2,3.00$ and $4.00 \mathrm{mgl}^{-1}$ ) with $0.05 \mathrm{mgl}^{-1} \mathrm{NAA}$ on multiplication of shoots is presented in (Table 2). The cytokinin free medium gave least average number of shoots indicating strong apical dominance BA stimulating the production of axillary shoots. The best number of shoots (3.89), shoot length (3.24) and number of leaves (24.22) C. spinosa were obtained with $0.50 \mathrm{mgl}^{-1}$ BA with $0.05 \mathrm{mgl}^{-1}$ NAA. These results indicated that BA plays a key role in shoot proliferation of $C$. spinosa. This finding agreement with Khattab and Ibenthal (2010) they found that the best shoot multiplication of $C$. spinosa when use MS medium supplemented with 0.40 or $0.20 \mathrm{mgl}^{-1} \mathrm{BA}$. However, Musallam (2011) found the WPM supplemented with $2.00 \mathrm{mgl}^{-1} \mathrm{BA}$ gave the highest number of shoots in $C$. spinosa

\section{Rooting stage: \\ Interaction effect of MS medium strength and type of auxin on rooting:}

About 3-4 cm long shoots were used for rooting experiment. The rooting response different according to $1 \mathrm{mgl}^{-1}$ IBA or $1 \mathrm{mgl}^{-1} \mathrm{NAA}$ as well as the strength of basal salt medium as shown in (Table 3 ). The results indicated that the half MS strength supplemented with 1 $\mathrm{mgl}^{-1}$ IBA was significantly surpassed NAA in increasing number of main roots (3.44), number of lateral roots (20.78), root length (7.30) and plant length (3.36).

\section{Effect of different medium state with half medium strength on rooting traits:}

The best medium state was semi solid medium with half strength supplemented with $1 \mathrm{mg}^{-1}$ IBA which gave the maximum number of main roots (2.44), number of lateral roots (32), root length (5.33) and plant length (2.31) as show in (Table 4). The same results were found by similar results obtained by Khosravi et al., (2007) they found the highest number of roots (4.35) and root length $(0.82 \mathrm{~cm})$ were achieved in semi solid medium with 1/4 MS strength for roses. On the other hand, Praveen et al., (2009) found that the liquid cultures were found suitable for proliferation of shoots versus the semi liquid medium in Bacopa monnieri.

\section{Effect of different concentration of IBA on rooting traits:}

The results concluded that the best No. of main roots (2.44), No. of lateral roots (32.00), root length (5.33) and plant length (3.03) were obtained when the half MS semi solid supplemented with $1.50 \mathrm{mg}^{-1}$ IBA (Table 5). Similarly, Rani and Rana (2010) found the best rooting of Tylophora indica was achieved in 1/2 MS medium with $0.5 \mathrm{mgl}^{-1}$ IBA fairly good shoot numbers and root length per shoot were obtained on contrast Khattab and Ibenthal (2010). They found the best root formation was with $4.0 \mathrm{mgl}^{-1}$ IBA. Various concentrations of IBA with full MS were helpful in inducing the roots of Capparis spinosa.

\section{Effect of Activated Charcoal with Different concentration of IBA:}

The root formation was significantly affected by the different treatments tested on C.spinosa (Table 6). The highest number of main roots (3.89), number of lateral roots (27.11), root length (4.54) and plant length (2.47) was observed as a result of amending the half-strength MS semi solid medium with $3.0 \mathrm{~g}$ AC $/ \mathrm{L}+1.50 \mathrm{mg}$ IBA /L. Similar observation were found Abdallah et al., (2009). Found that the half MS strength supplemented with $1 \mathrm{mg} / 1$ auxin (IBA orNAA) with $3 \mathrm{mg} / 1$ charcoal gave the highest root percentage $(63 \%)$ for ficus anastasia. However, Abou Dahab et al., (2010) found that the half strength WPM medium $+1.0 \mathrm{~g}$ activated charcoal $(\mathrm{AC}) / 1+0.5 \mathrm{mg}$ IBA/l was the best medium for in vitro rooting percentage and root number/shoot let. The favourable effect of AC rooting was mainly due to adsorption of auxin (Abdallah et al., 2009).

\section{Acclimatization:}

Plantlets regenerated in vitro with well developed root system were transferred to plastic pots containing mixture of peat-moss and vermiculite $(1: 1 \mathrm{v} / \mathrm{v})$ under controlled growth conditions. To maintain high relative humidity, pots were placed in plastic bags. Relative humidity was reduced gradually and complete removal of plastic bag took place after two weeks of placement. The pots with the plantlets were kept in greenhouse for three weeks for acclimatization. Normal growth of potted plants was visible 10-15 days after transfer to field conditions. The same results obtained with Musallam (2011). Successfully transferred in vitro regenerated plants of $C$. spinosa into the filed using plastic pots containing soil mix with perlite and compost $(1: 1 \mathrm{v} / \mathrm{v})$. Also, Khattab and Ibenthal (2010) found the rooted plantlets which transferred to a mixture of floraton 3: sand (1:1) successfully survive (90\%) after 30 days in filed for C. spinosa.

\section{CONCLUSIONS}

The protocol defined in this study as outlined below and is demonstrated in Fig.1, was found to be efficient and can be utilized for cloning of selected wild plants of this species. Firstly, establishment of In vitro shoots from nodal explants on MS medium. Then multiply, the shoots on MS medium $+0.50 \mathrm{mgl}^{-1} \mathrm{BA}+0.05 \mathrm{mgl}^{-1}$ NAA. Moreover, rooting the shoots on $1 / 2 \mathrm{MS}$ semi solid $+1.5 \mathrm{mgl}^{-1}$ IBA alone or with $2.00 \mathrm{gl}^{-1} \mathrm{AC}$. Finally hardening the rooted shoots in greenhouse in pots containing mixture of peat-moss and vermiculite $(1: 1 \mathrm{v} / \mathrm{v})$. The finding has several implications for managing the diversity of this species, as well as restoration of its degradation. The developed protocol can be used to produce uniform and desirable plants for cultivation in order to reduce pressure on the wild population special in North Sinai. It also offers potential system that should be used for improvement, conservation and mass propagation of C. Spinosa. 
Table (6): Effect of different concentration of IBA of half MS semi solid strength, $2 \mathrm{gl}^{-1}$ activated charcoal and on number of main roots, number of lateral roots, root length and plant length

\begin{tabular}{cccccc}
\hline $\begin{array}{c}\text { Activated } \\
\text { Charcoal } \\
\text { Conc. }\end{array}$ & $\begin{array}{c}\text { IBA } \\
\text { Conc. }\end{array}$ & $\begin{array}{c}\text { No. of } \\
\text { main roots }\end{array}$ & $\begin{array}{c}\text { No. of } \\
\text { lateral roots }\end{array}$ & $\begin{array}{c}\text { Root } \\
\text { Length (cm) }\end{array}$ & $\begin{array}{c}\text { plant } \\
\text { length (cm) }\end{array}$ \\
\hline & 0.00 & $2.11^{\mathrm{c}}$ & $14.11^{\mathrm{c}}$ & $3.14^{\mathrm{b}}$ & $2.52^{\mathrm{b}}$ \\
$\mathrm{AC}$ & 0.50 & $3.00^{\mathrm{b}}$ & $15.11^{\mathrm{c}}$ & $3.53^{\mathrm{b}}$ & $2.58^{\mathrm{b}}$ \\
$2 \mathrm{gl}^{-1}$ & 1.00 & $3.22^{\mathrm{ab}}$ & $19.00^{\mathrm{b}}$ & $3.53^{\mathrm{b}}$ & $2.76^{\mathrm{b}}$ \\
& 1.50 & $3.89^{\mathrm{a}}$ & $27.11^{\mathrm{a}}$ & $4.54^{\mathrm{a}}$ & $2.47^{\mathrm{a}}$ \\
\hline
\end{tabular}

Means followed by the same letter within each column are not significantly different at 0.05 level of probability according to Duncan's multiple range test

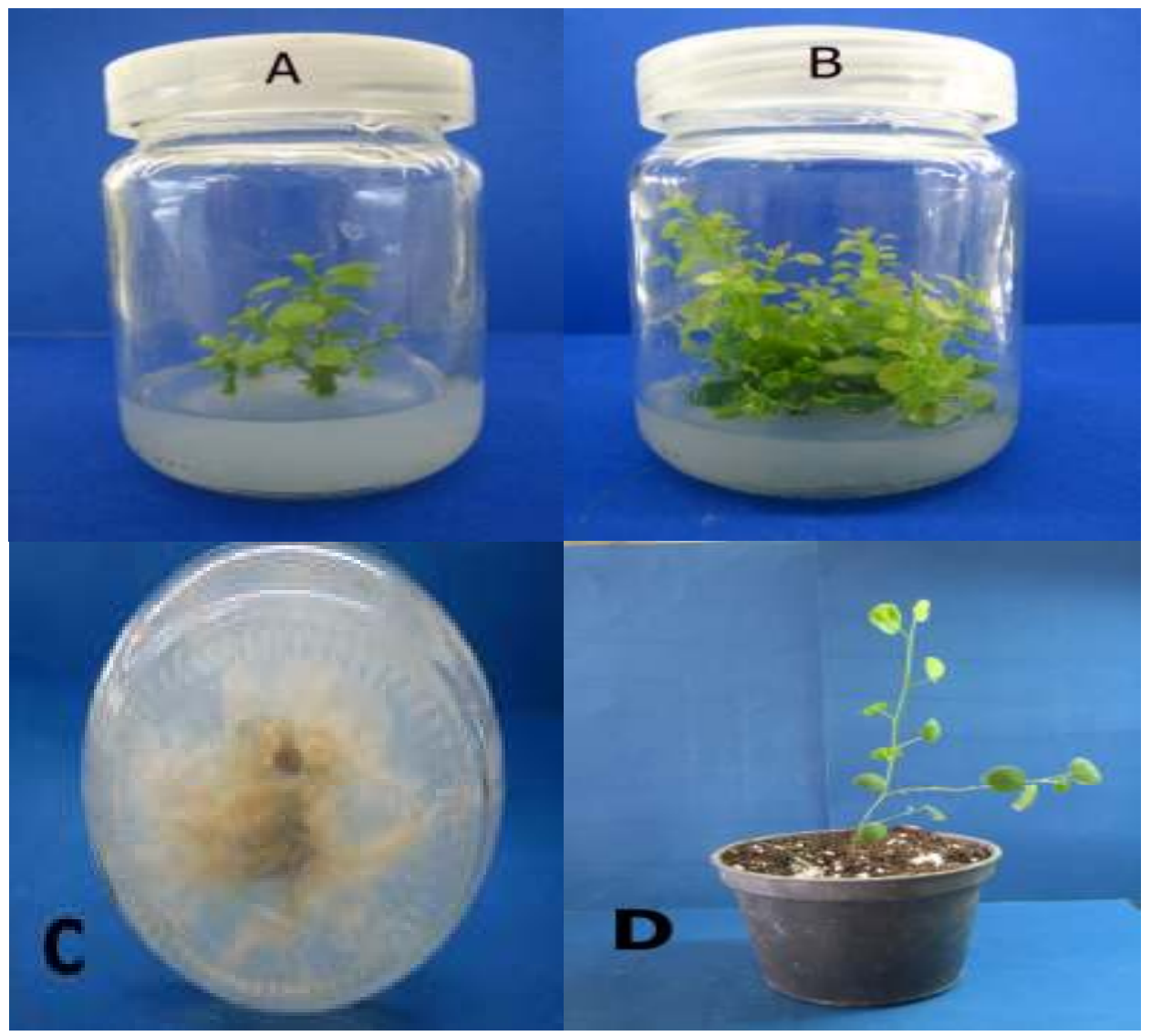

Figure (1): Micropropgation of C. Spinosa from mature plant. (A) in vitro shoot establishment from nodal explants on MS medium (B) Multiplication of shoots on Ms medium $+0.50 \mathrm{mgl}^{-1} \mathrm{BA}+0.05 \mathrm{mgl}^{-1} \mathrm{NAA}$ (c) Development of roots on MS semi solid $+1.50 \mathrm{mgl}^{-1}$ IBA with $2 \mathrm{gl}^{-1}$ AC (D) Plant raised after transplantation to potting mixture.

conservation of this drought-tolerant plant can be a challenge as well as a powerful tool to reduce desertification, improve farmers livelihoods and enhance biodiversity.

\section{REFERENCES}

Abdulla A. H.S., A. Malki and K.M.S. Elmeer (2009). Effect of Meduim strength and charcoal combined with IBA dnd NAA on root intiation of Ficus anastasia. Academic Journal of Plant Sciences 2(3): 169-172.
Abou Dahab, A.M., A.M., Habib; M.K., El-Bahr and A.M.M. Gabr (2010). Establishment of an in vitro propagation protocol for Taxodium distichum and Taxodium distichum var. 'distichum'. Nature and Science (8):9.

Al-safadi, B. and R. Elias (2011). Improvement of caper (Capparis spinosa L.) propagation using in vitro culture and gamma irradiation.Scientia Horticulturae. 127:290-297.

Ancora, G. and L. Cuozzo (1985). In vitro propagation of caper (Capparis spinosa L.). Geneyica Agraria, 39 (3): $304-305$.

Caglar, G.; S. Caglar; O. Ergin and M. Yarim (2005).The influence of growth regulators on 
shoot proliferation and rooting of in vitro propagated Caper. J. of environmental Biology. 26(3):479-485.

Carra, A.; M. B. D. Signore; F. Sottile; A. Ricci, and F. Carimi (2011). Potential use of new diphenylurea derivatives in micropropagation of Capparis spinosa L. Plant Growth Regul, 66:229-237.

Carra, A.; M. B. D. Signore; F. Sottile; A. Ricci, and F. Carimi (2012). In vitro plant regeneration of caper (Capparis spinosa L.) from floral explants and genetic stability of regenerants Plant Cell Tiss Organ Cult, 109:373-381.

Chalak, L. and A. Elbitar (2006).Micropropagation of Capparis spinosa L. subsp. rupestris Sibth. \& Sm. by nodal cuttings. Indian Journal of Biotechnology 5: 555-558.

Chahar, O.P.; P. Kharb; S. F. Ali, P. Batra and V.k. Chowdhury (2010). Devolpment of protocol on micropropgation in Ker (capparis deciduas (Forsk) Edgew). World Applied Sciences Journal. 10(6): 695-698.

Duncan, D. B. (1995). Multiple range and multiple Ftest. Biometrics, 11: 1-42.

Germana, M. A. and B. Chiancone (2009): In vitro germination and seedling development of caper (Capparis spinosa L.) mature seeds. Acta Hort. (ISHS) 839: 181-186.

Horshati, E. and E. Jambor-Benczur (2006). In vitro Propagation of Cappris spinosa. V International Symposium on In vitro Culture and Horticultural Breeding, 30 Nov.

Hassanein, R. A.; M. F. Gabr; A. M. Ahmed and Ghada A. Hegazi (2008). Micropropagation of Capparis cartilaginea Decne. Catrina Journal : Archive : 3(3).

Khattab, S. H. A. and W.D. Ibenthal (2010). In vitro propagation protocol for preservation of some wild medicinal plants genotypes grown in Sinai, Egypt. The Sixth Inter. Conf. of Sustain. Agric. And Develop. Fac. Of Agric., fayoum Univ., $27-$ 29.

Khosravi P., M.J. Kermani, G.A. Nematzadeh. M.R. Bihamta (2007). A protocol for mass production of Rosa hybrida cv. Iceberg through in vitro propagation. Iran. J. Biotechnol. 5(2): 100-104.

Linsmaier, E. M., and F. Skoog (1965).Organic growth factor requirements of tobacco tissue cultures. Physiol. Plant. 18:100-128.
Movafeghi A, H. Ghader and M. Aliasgharpour (2008) Regenaretion of Capparis spinosa L. using hypocotyl explants. Iranian J. Biol. 21:289-297.

Murashige, T.; F. Skoog (1962). A revised medium for rapid growth and bioassays with tabacco tissue cultures. Phsiol. Plant. 15: 473-497.

Musallam, I., M. Duwayri and R. A. Shibli, (2011). Micropropagation of caper (Capparis spinosa L.) from wild plants. Functional Plant Science and Biotechnology, 5: 17-21.

Nitsch, J. P. and C. Nitsch (1969). Haploid plants from pollen grains. Science 163:85-87.

Pottino, B. O. (1981). Methods in plant tissue culture. Dept. of hort. Agric. College Maryland Univ. College park, Maryland USA. pp. 8-29.

Praveen N., P. M. Naik, S. H. Manohar, A. Nayeem and H. N. Murthy (2009). In vitro regeneration of brahmi shoots using semisolid and liquid cultures and quantitative analysis of bacoside A. Acta Physiol Plant 31:723-728.

Raafat, H.; R. H. Abd El-Wahab; M.S. Zaghloul; W. M. Kamel, and A. R. Moustafa (2008). Diversity and distribution of medicinal plants in Sinai, Egypt. African Journal of Environmental Science and Technology. 2 (7):157-171.

Rani, S. and J. S. Rana (2010). In vitro propagation of Tylophora indica- Influence of Explanting Season, Growth Regulator Synergy, Culture Passage and Planting Substrate.Journal of American Science. 6:12.

Rodriguez, R.; M. Rey; L. Cuozzo, and G. Ancora (1990). In Vitro propagation of caper (Capparis spinosa L.).In vitro cell.Dev.Biol.26:531-536.

Salem A.B., H. Zemni and A. Ghorbel (2001) Propagation of caper (Capparis Spinosa L.) by herbaceous cuttings and in vitroculture. Agric Med 31:42-48.

SAS (2004). SAS/STAT User's Guide. SAS Institute Inc., Cary, N.C.

Solyer, A. and V. Khawar (2007): Seed germgermination of Caper (Capparis Ovata Var. Herhacea) Using a Naphthalene Acetic Acid and Gibberellic Acid. Int. J. Agri. Biol., 9(1): 35-37.

Tansi, S. (1999). Propagation methods for Caper (Capparis spinosa L.). Agricolltura Mediterranea, 129: 45-49.

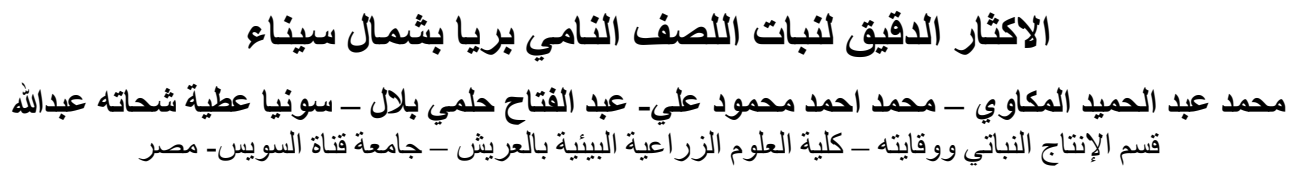

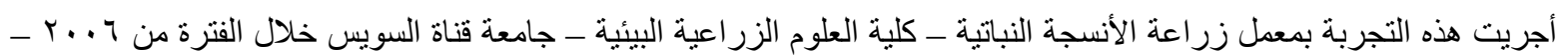

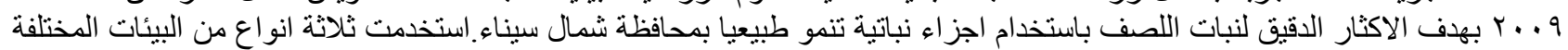

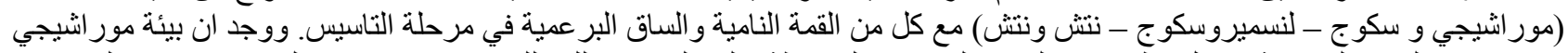

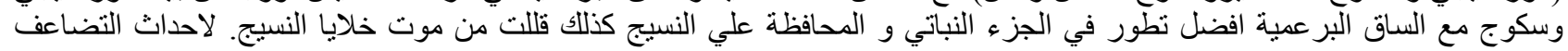

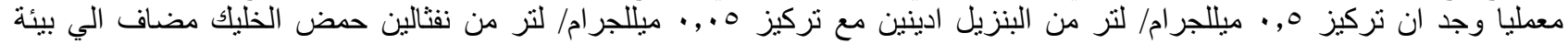

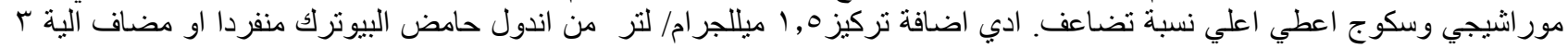

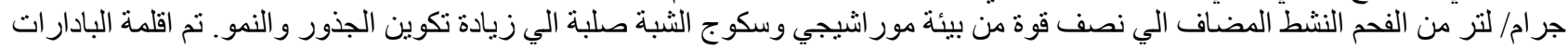

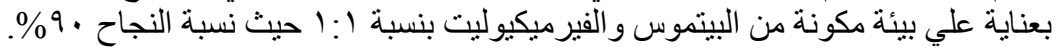

